\title{
TO THE ANTELOPE RESCUE
}

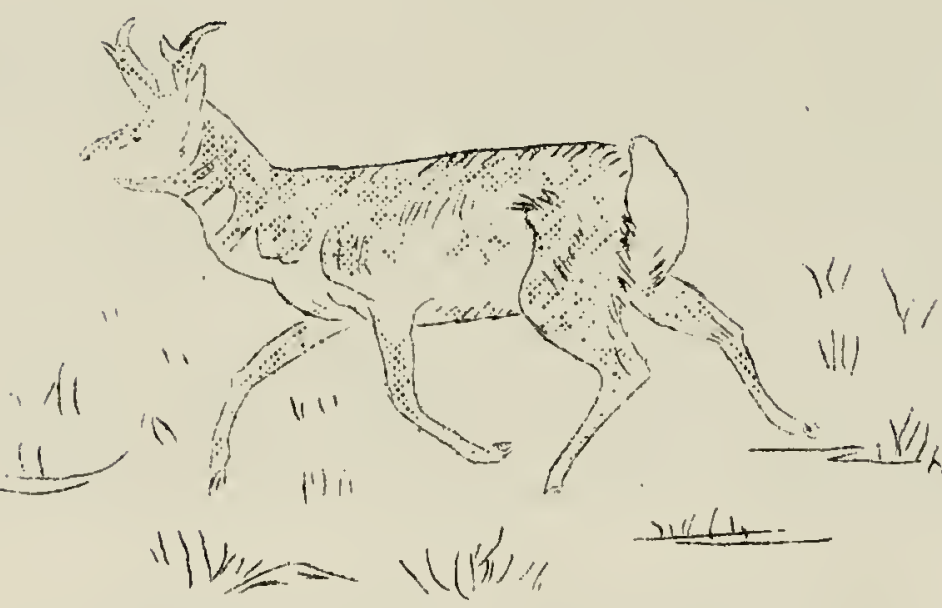

Following up reports that some 600 or more antelope were wandering futively over areas of Southwestern Saskatchewan, searching for food in drifting snow and in forty and fifty below weather, the game branch of the provincial natural resources department chartered an R.C.A.F. twin-engine Dakota from Winnipeg, and on Sunday, January 29, flew from Rogune over the area bringing relief to the herds. Four tons of baled alfalfa hay were dropped in the vicinities of Neville, Gull Lake and McCord.

Accompanying the Dakota on its two mercy trips that day were Natural Resources Minister J. H. Brockelbank, Game Commissioner Paynter, Game Supervisor W. A. Hartwell and Fred Bard, director of the provincial museum.

Mr. Bard informs us that the antelope seemed to have considerable strength judging by the speed with which they ran, particularly on the second approach of the planeas it circled over an area. There was considerable snow, and it was badly drifted in places. The bales were dropped from a height of from 150 to 200 feet and from that distance the animals could clearly be seen. On striking the ground the bales burst open and the alfalfa was scattered over a considerable area.

Just why these animals wandered so far east from the foot-hills is not clearly understood. Perhaps they were driven there by cold winds and storm conditions from the northwest. Certainly their conditions for grazing were not improved. Some of the herds are now in extremely dried-out regions. The food dropped will, in all. likelihood, protect them from danger until normal temperatures return.

\section{IONG-TAIIED WEASEL}

By Vm. Yanchinski

I would like to pass on some observations on rodent control abilities of this animal.

One day, a few weeks ago, I noticed a weasel, with a mouse in its jaws, come out of a barn, lope across the yard and duck under a small granary where apparently it had taken up temporary quarters. In a matter of minutes it made at least two more trips, each time with a mouse between its teeth. The barn, though unoccupied at present, was once used for storing grain and this provides an attractive abode for the mice.

I have traced weasel tracks into granaries and other buildings where there were abundant signs of house rats. Invariably, after these periodic visits from the weasels, these signs would disappear, indicating the shortsightedness with which these little killers had gone about cleaning out the rodents. I do not hesitate to say that if given a chance, this ferocious little animal can do more in keeping rats and mice under control in rural commities than any measures man hinself can devise. 